\title{
PERMASALAHAN TUBERKOLOSIS DI BEBERAPA KOTA DI PROVINSI BANTEN
}

\author{
Aulia Zikry Bunga Mentari ${ }^{1}$, Savitri Hurriatul Maula ${ }^{1}$ \\ ${ }^{1}$ S1 Kesehatan Masyarakat UPN Veteran Jakarta \\ Email: auliazikrybunga@upnvj.ac.id
}

Penyakit Tuberkulosis merupakan permasalahan kesehatan global yang telah menjadi perhatian dunia. Tuberkulosis (TB) adalah penyakit infeksi yang menular disebabkan oleh kuman kelompok Mycobacterium yaitu Myobaterium Tuberculosis . Penularannya melalui udara dan sumber penularannya adalah pasien TB yang dahaknya mengandung kuman TB. Gejala umum TB pada orang dewasa adalah batuk yang terus menerus disertai dahak selama kurang lebih 2 minggu. Faktor-faktor yang mempengaruhi ketidakberhasilan pengobatan TB adalah tingginya prevalensi pasien yang mangkir berobat, menolak minum obat, tingginya laki-laki usia produktif menyebabkan penularan lebih luas, hal ini karena banyak laki-laki yang keluar untuk mencari nafkah (Pulungan \& Permatasari, 2021).

Menurut hasil riskesdas tahun 2018, Provinsi Banten memiliki jumlah penderita tuberkulosis paru nomer satu seIndonesia (Kementerian Kesehatan RI, 2018). Kabupaten/Kota di Provinsi Banten dengan CNR TB BTA positif tertinggi Tahun 2019 adalah Kabupaten Tangerang 6.089 per 100.000 penduduk, diikuti Kota Tangerang Selatan 3.844 per 100.000 penduduk, dan Kabupaten Serang 3.568 per 100.000 penduduk. Kabupaten/kota dengan CNR TB BTA positif terendah adalah Kota Serang 32 per 100.000 penduduk, diikuti Kota Cilegon 1.294 per 100.000 penduduk, dan Kota Tangerang 2.150 per 100.000 penduduk (Dinas Kesehatan Provinsi Banten, 2002).

Angka Kesembuhan Tuberkulosis Paru terkonfirmasi bakteriologis tahun 2019 dengan angka tertinggi adalah Kabupaten Tangerang dengan jumlah 1.784 orang. Kabupaten / Kota dengan Persentase pengobatan lengkap semua kasus tuberkulosis tertinggi adalah Kabupaten Pandeglang dengan 76,2 \% dari jumlah semua kasus tuberkulosis yang terdaftar dan terobati. Persentase pengobatan lengkap semua kasus tuberculosis di Provinsi Banten tahun 2019 adalah 56,7 \% (Dinas Kesehatan Provinsi Banten, 2002).

Pada hasil penelitian Rismawati di Kota Tangerang Selatan, hal yang menjadi alasan mengapa Kota Tangerang Selatan menjadi salah satu kota di Provinsi Banten yang angkanya tinggi adalah karena tingkat pengetahuan responden terkait cara penularan penyakit TB tergolong masih kurang terkait kebiasaan atau perilaku yang mudah menularkan TB. Rata-rata responden menjawab tentang penyebab penyakit TB adalah berasal dari debu kotor saja tanpa 
mengetahui bahwa sebenarnya ada bakteri atau kuman yang ada di udara. Hasil lainnya menemukan bahwa Responnya tidak mengetahui bahwa pengobatan TB harus berkelanjutan selama 6 bulan dan tidak boleh terputus, karena jika terputus, maka harus memulai lagi dari nol bulan atau dari awal lagi (Pangestika, Fadli, \& Alnur, 2019).

Menurut Peraturan Menteri Kesehatan Republik Indonesia Nomor 67 Tahun 2016 Tentang Penanggulangan Tuberkulosis Penanggulangan Tuberkulosis adalah segala upaya kesehatan yang mengutamakan aspek promotif dan preventif, tanpa mengabaikan aspek kuratif dan rehabilitatif yang ditujukan untuk melindungi kesehatan masyarakat, menurunkan angka kesakitan, kecacatan atau kematian, memutuskan penularan, mencegah resistensi obat dan mengurangi dampak negatif yang ditimbulkan akibat Tuberkulosis (MENTERI KESEHATAN REPUBLIK INDONESIA, 2016).

Program yang dicanangkan untuk mencegah penularan penyakit TB di Banten salah satunya adalah Gerakan Banten Eliminasi TB. Prinsip dan strategi dalam gerakan ini adalah menemukan orang dengan "batuk berdahak", menentukan terduga TB dengan pemeriksaan lanjutan di fasynkes baik itu lab maupun klinis, mengobati semua kasus secara efektif untuk mengurangi angka kematian dan kesakitan, pengendalian risiko TB dengan lingkungan dan Rumah Sehat. Rumah dapat dikatakan rumah sehat dilihat dari ventilasi, pencahayaan, jenis lantai, jenis dinding, kelembaban, suhu dan kepadatan hunian.
Hanbatan dalam penerapan Gerakan Banten Eliminasi TB adalah banyaknya kasus TB yang masih belum terlaporkan atau under reporting (Amri, 2018, Mathofani \& Febriyanti, 2020)

Program lain terkait pencegahan penularan penyakit TB adalah gerakan TOSS TB atau Gerakan Temukan Tuberkulosis, Obati Sampai Sembuh. Gerakan ini merupakan gerakan yang dicanangkan oleh pemerintah untuk mengatasi penularan penyakit TB di Indonesia. Terjadi perubahan strategi yang awalnya penemun promotif pasif berubah menjadi aktif, intensif, dan masif. Melakukan penemuan kasus TB aktif dapat dilihat melalui penemuan kasus berbasis keluarga dan masyarakat khusus, meningkatkan jejaring layanan dengan adanya keterlibatan RS dan klinik swasta, serta peningkatan kolaborasi layanan di fasyankes. Hambatan yang dialami dalam penerapan gerakan TOSS TB ini adalah meningkatnya TB MDR (Multi Drug Resistence) yang mempersulit pasien $\mathrm{TB}$ untuk bias sembuh karena pasien menjadi resiste terhadap obat anti TB (Kementerian Kesehatan RI, 2017).

Program terakhir adalah Gerakan Ketuk Pintu. Gerakan ini bersifat nasional. Gerakan ini merupakan gerakan dimaka kader wilayah setempat melakukan kunjungan dari rumah ke rumah. Kunjungan dilakukan untuk melakukan promosi kesehtan terkait TB dan skrining terduga penyakit TB dan membujuk pasien terduga TB untuk mau melakukan pengoatan di fasilitas pelayanan kesehatan. Gerakan ini berkaitan dengan gerakan TOSS TB karena 
setelah melakukan gerakan ketuk pintu akan dilanjutkan dengan gerakan TOSS TB dimana pasien TB dirujuk ke fasilitas pelayanan kesehatan untuk mendapatkan pengobatan sampai pasien sembuh. Hambatan yang ada terkait pelaksanaan program ini adalah kurangnya tenaga kader untuk dapat melakukan gerakan ketuk pintu secara keseluruhan, terutama di daerah dengan akses yang sulit (Dinkes Tanah Bumbu, 2018).

\section{DAFTAR PUSTAKA}

Amri, H. (2018). Gerakan Banten Eliminasi TB sebagai Upaya Percepatan Pemberantasan TB di Provinsi Banten. Jurnal Lingkar Widyaiswara, 5(1). Retrieved from http://juliwi.com/published/E0501/j1w0 501_1-9.docx.pdf

Dinas Kesehatan Provinsi Banten. (2002). Profil Kesehatan Provinsi Banten.

Dinkes Tanah Bumbu. (2018). GERAKAN KETUK PINTU DALAM RANGKA HARI TB SEDUNIA TAHUN 2018. Retrieved from http://dinkes.tanahbumbukab.go.id/gera kan-ketuk-pintu-dalam-rangka-hari-tbsedunia-tahun-2018/

Kementerian Kesehatan RI. (2017). Cara Terbaik Mencegah TB Resistan Obat adalah Promosi Pengobatan TB dengan TOSS TB.

Kementerian Kesehatan RI. (2018). Hasil Utama Riskesdas 2018. Retrieved from http://www.depkes.go.id/resources/dow nload/infoterkini/materi_rakorpop_201 8/Hasil Riskesdas 2018.pdf

Mathofani, P. E., \& Febriyanti, R. (2020).
Faktor-Faktor Yang Berhubungan Dengan Kejadian Penyakit Tuberkulosis ( TB ) Paru di Wilayah Kerja Puskesmas Serang Kota Tahun 2019 The Factors Associated With The Incidence Of Pulmonary Tuberculosis In The Working Area Of Serang City Health Center 2019. Jurnal Ilmiah Kesehatan Masyarakat, 12, 1-10.

\section{MENTERI KESEHATAN REPUBLIK}

INDONESIA. (2016). Peraturan menteri kesehatan Republik Indonesia Nomor 67 Tahun 2016 tentang Penanggulangan Tuberkolosis.

Pangestika, R., Fadli, R. K., \& Alnur, R. D. (2019). Edukasi Pencegahan Penularan Penyakit Tb Melalui Kontak Serumah. Jurnal Solma, 8(2), 229-238.

Pulungan, R. M., \& Permatasari, P. (2021). Predisposing and Enabling Factors Relationship with Successful Treatment of Pulmonary Tuberculosis (TB). Jurnal Kesehatan Prima, 15(1), 57-67. 